\title{
Influence of Rootstocks on the Resistance of Grafted Cucumber (Cucumis sativus L.) Scions to Powdery Mildew (Podosphaera xanthii U. Braun \& N. Shishkoff)
}

\author{
Yoshiteru Sakata $^{1 *}$, Mitsuhiro Sugiyama ${ }^{1}$, Takayoshi Ohara ${ }^{1}$ and Masami Morishita ${ }^{2}$ \\ ${ }^{\prime}$ National Institute of Vegetable and Tea Science (NIVTS), National Agricultural Research Organization (NARO), \\ Kusawa 360, Ano, Tsu 514-2392, Japan \\ ${ }^{2}$ National Agricultural Research Center for Hokkaido Region (NARCH), National Agricultural Research Organization (NARO), \\ Hitsujigaoka 1, Toyohira, Sapporo 062-8555, Japan
}

\begin{abstract}
Whether or not powdery mildew resistant and susceptible rootstock cultivars would impart these characteristics to the grafted cucumber scions was investigated. Two newly released pumpkin rootstock cultivars used for bloomless cucumber production, 'Tokiwa Power Z' and 'White Power', were found to be highly resistant to powdery mildew from the seedling stage (tested parts: cotyledons) to the adult stage (tenth true leaves) at cool to moderate temperatures. The accession PPMR-1, a blooming rootstock, showed moderate to high levels of resistance, especially during the adult stage. The conventional bloomless rootstock 'Hikari Power Gold' and the conventional blooming rootstock 'Shin-tosa' were found to be susceptible. The rootstocks had little to no influence on the resistance to powdery mildew of the grafted scions at younger stages, even though the levels of resistance of the rootstock cultivars differed considerably. Scions, grafted onto PPMR1 or 'Shin-tosa' rootstocks, showed increasing powdery-mildew resistance or tolerance with growth (tested parts: fifth and seventeenth true leaves). The powdery-mildew-resistant 'Tokiwa Power Z' and 'White Power' did not impart high levels of resistance to scions, whereas 'Hikari Power Gold', which is used for bloomless cucumber production, reduced the resistance of scions to powdery mildew. These results indicate that rootstock cultivars, including certain pumpkin rootstocks, e.g., PPMR-1, can alter the powdery-mildew resistance or tolerance of cucumber scions at the adult stage.
\end{abstract}

Key Words: cucumber, grafting, powdery mildew, resistance, rootstock.

\section{Introduction}

The main objectives of grafting cucumbers are to avoid soilborne diseases and to obtain higher yields than with non-grafted seedling plants. Grafting contributes to sustainable agriculture by reducing the amount of agrochemicals used for disinfecting soil and higher yields result in higher income for farmers. In Japan, the use of the pumpkin cultivars 'Shirokikuza' (Cucurbita moschata Duch.) and 'Shin-tosa' (C. maxima Duch. $\times C$. moschata), as rootstocks for the production of cucumber (Cucumis sativus L.), began around 1960 (Fujieda, 1994) and is now common, being used at rates of up to $80 \%$ generally and nearly $100 \%$ in glass and plastic greenhouse production. This practice reduces damage from Fusarium wilt (Fusarium oxysporum Schlechtendahl f. sp. cucumerinum Owen) and also increases yield. Moreover, grafting makes the plants tolerant to cool temperatures (Oda, 2002). In the mid1980 s, the adoption of a new type of pumpkin cultivar (Cucurbita moschata), which does not bloom, allowed

Received; April 20, 2005. Accepted; August 22, 2005.

* Corresponding author (E-mail: ysakata@affrc.go.jp). the production of attractive, lustrous cucumber fruits.

However, the use of bloomless rootstock cultivars was observed to alter several characteristics of the grafted cucumbers, such as their susceptibility to disease. Hazama et al. (1993) reported that the use of these rootstocks resulted in an increased incidence of more severe damage by powdery mildew (Podosphaera xanthii [Castaggne] U. Braun \& N. Shishkoff). In contrast, Morishita et al. (1999) observed the suppression of powdery mildew growth on the leaves of a susceptible cultivar grafted onto a resistant wild-type cucumber. These results suggest that the rootstock may transmit the resistance of cucumber scions to powdery mildew.

Recently, several new bloomless rootstock cultivars that exhibit tolerance to powdery mildew have been released by Japanese cucumber seed companies. There is demand for new bloomless rootstock cultivars that confer powdery-mildew tolerance or resistance to cucumber scions, although the potential effects of grafting are unclear. We had selected a powdery-mildew resistant pumpkin (C. moschata) accession, PPMR-1, from a local Japanese cultivar of 'Shima-kabocha' (unpublished). And the powdery-mildew-resistant cucumber accession PI 197088-1 had been selected previously from the Indian wild-type cucumber 
accession PI 197088 (Morishita et al., 2002). The many pumpkin and cucumber cultivars with various levels of powdery-mildew resistance that have recently become available were used to investigate the influence of rootstocks on the occurrence of powdery mildew on cucumber scions.

In this study, we examined the powdery-mildew resistance of the rootstock cultivars, including the newly released bloomless rootstock cultivars and the influence of these rootstock cultivars on the resistance of cucumber scions.

\section{Materials and Methods}

\section{Plant materials}

The rootstocks and scions (Table 1): 'Hikari Power Gold' (HP), 'Agura' (AG), 'All-Star' (AS), 'King Kitora' (KK), and 'Tokiwa Power Z' (TP) are $\mathrm{F}_{1}$ hybrid rootstock cultivars of C. moschata Duch. PPMR-1 (PM) was selected from the local Japanese $C$. moschata cultivar 'Shima-kabocha' and is resistant to powdery mildew (unpublished). 'White Power' (WP) and 'Shintosa' (ST) are interspecific $\mathrm{F}_{1}$ hybrid rootstocks between C. maxima Duch. and C. moschata. HP, AG, AS, KK, $\mathrm{TP}$, and WP are rootstock cultivars used for bloomless fruit production. AG, AS, TP, and WP that were released recently are claimed by their distributors to show tolerance to powdery mildew. ST is a conventional Japanese rootstock cultivar, whereas 'Shishigadani' (SS) is a local Japanese C. moschata cultivar. 'Encore 10' (A10) is a typical Japanese cultivar whose fruits grow to about $20 \mathrm{~cm}$ and weigh $100-120 \mathrm{~g}$; it is highly susceptible to powdery mildew. A10 was used as a scion and rootstock; PI 197088-1 (PI) is powdery mildew resistant (Morishita et al., 2002).

\section{Powdery-mildew resistance of rootstock cultivars}

To evaluate the resistance of the rootstock cultivars, seeds were sown in plastic pots $(9 \mathrm{~cm}$ diam.) filled with the sterilized and fertilized soil mix, Engei-baido (Kureha Chemical Industry Co., Ltd. Japan); the plantlets were grown in a greenhouse.

Powdery mildew used in this study was Podosphaera xanthii [Castaggne] U. Braun \& N. Shishkoff, formerly known as Sphaerotheca fuliginea. Preparation of the inoculum, inoculation by spraying leaf with a conidial suspension $\left(10^{5} / \mathrm{mL}\right)$ and incubation them as described by Morishita et al. (2002).

Cotyledons detached from various rootstock cultivars for the first test, were inoculated and incubated at $20^{\circ} \mathrm{C}$ or $26^{\circ} \mathrm{C}$ because the resistant reaction of some cucumber cultivars is temperature-dependent (Morishita et al., 2002). The first true leaves of rootstock-plantlets for the second test were inoculated at the three-leaf stage and were grown in a plastic greenhouse. For the third test, the tenth true leaves on seven rootstock plants of each cultivar were planted in a plastic greenhouse without replication on 30 May 2002; they were inoculated 4 weeks after transplanting.

The disease index for evaluating the resistance of each plant was assessed on a $0-9$ scale $(0=$ no visible symptoms to $9=$ completely covered with mycelia with dense conidia). The disease-index data were analyzed with a Kruskal-Wallis ANOVA by using Stat Macros (developed by $\mathrm{T}$. Hirota, International Christian University, Japan).

\section{Powdery-mildew resistance of cucumber scions grafted onto rootstocks}

To evaluate the influence of the rootstocks, seeds were sown in vermiculite and grown in a germination cabinet kept at $30^{\circ} \mathrm{C}$. Nine to 13 days after sowing, individual scions and rootstocks were united at the hypocotyls by using the approach-grafting method; the grafted plants were transplanted into $9 \mathrm{~cm}$ plastic pots as above. Nine to 12 days after grafting, the root systems of the scions were severed.

Table 1. The plant materials used in this study.

\begin{tabular}{lcccl}
\hline \hline Species/Cultivar name & Cultivar abbreviation & Cultivar type & Bloom & \multicolumn{1}{c}{ Source } \\
\hline Cucurbita moschata & & & & \\
Hikari Power Gold & HP & $\mathrm{F}_{1}$ & No & Tokiwa Kenkyujo, JP \\
Agura & $\mathrm{AG}$ & $\mathrm{F}_{1}$ & No & Kurume Vegetable Breeding Co., LTD, JP \\
All Star & $\mathrm{AS}$ & $\mathrm{F}_{1}$ & No & SaitamaGensyu Ikuseikai Co., LTD, JP \\
King Kitora & $\mathrm{KK}$ & $\mathrm{F}_{1}$ & No & Nanto Seed Co., LTD, JP \\
Tokiwa Power Z & $\mathrm{TP}$ & $\mathrm{F}_{1}$ & No & Tokiwa Kenkyujo, JP \\
PPMR-1 & $\mathrm{PM}$ & pure-bred & Yes & Selection from a local variety of 'Shimakabocya' of Okinawa, JP \\
Shishigadani & $\mathrm{SS}$ & pure-bred & Yes & Local variety of Kyoto, JP \\
C. maxima $\times$ C. moschata & & & & \\
White Power & WP & $\mathrm{F}_{1}$ & No & Tokiwa Kenkyujo, JP \\
Shin-tosa & $\mathrm{ST}$ & $\mathrm{F}_{1}$ & Yes & Tokiwa Kenkyujo, JP \\
Cucumis sativus & & & & \\
Encore 10 & P10 & $\mathrm{F}_{1}$ & Yes & Tokiwa Kenkyujo, JP \\
PI 197088-1 & PI & pure-bred & Yes & Selection from a PI 197088 of Indian wild cucumber \\
\hline
\end{tabular}


Cotyledons, detached from scions grafted onto various rootstocks for first test, were inoculated and incubated at $20^{\circ} \mathrm{C}$. The fifth true leaves of the grafted plantlets for the second test were inoculated and the plantlets were incubated as above. For the third test, the seventeenth true scion leaves on 14 grafted plants of each paired combination were inoculated on 20 December 2001, 30 May 2002, and 22 September 2004, respectively and the plants were grown in a plastic greenhouse that was kept above $15^{\circ} \mathrm{C}$. The Japanese standard training system for cucumber, which consisted of a single vine trained vertically and lateral shoots pinched at one or two nodes, was used. Inoculations to seventeenth leaves were performed $4-8$ weeks after transplanting. A plant, grafted onto a rootstock of cultivar HP, is referred to as HPgrafted; similar descriptions are used for the other cultivars.

\section{Results and Discussion}

Powdery-mildew resistance of rootstock cultivars

The powdery-mildew resistances of the rootstock cultivars (Table 2,3) reveal that TP, WP, and PI, tested by detached cotyledons incubated at $20^{\circ} \mathrm{C}$, were the most resistant. The symptoms on the leaf surfaces of these cultivars were nearly undetectable, because they exhibited very few sporulations under microscope. HP, AG, AS, SS, ST, and A10 were severely infected and thus regarded as susceptible, while PM was moderately resistant. Nearly identical results were obtained when the cultivars were incubated at 20 or $26^{\circ} \mathrm{C}$. TP and WP, the newly released bloomless rootstock cultivars, were highly resistant compared with the conventional rootstock cultivars HP (bloomless type) and ST (blooming type). The claimed resistances of AG and AS were not confirmed, but the resistance of PI, which had been selected as a highly resistant cucumber cultivar, was confirmed. PM has been regarded as resistant, but at the cotyledonary stage, it was not completely so.

The cultivars that showed the most resistance in the first true leaves were TP and PI. PM also showed complete resistance in this test, but incomplete resistance in another (data not shown). The resistance of PM was therefore deemed to be moderate; HP, ST, and A10 were severely infected.

The accession/cultivar that showed the most resistance in the tenth true leaves were PM and PI, lacking any

Table 2. Powdery mildew resistance in detached cotyledons of rootstock cultivars.

\begin{tabular}{lllll}
\hline \hline \multirow{2}{*}{ Rootstock cultivar } & \multicolumn{3}{c}{ Disease index $^{\mathrm{z}}$} \\
\cline { 2 - 6 } & $20^{\circ} \mathrm{C}\left(\mathrm{RE}^{\mathrm{y}}\right)$ & $26^{\circ} \mathrm{C}(\mathrm{RE})$ \\
\hline Hikari Power Gold & $8.5 \mathrm{a}^{\mathrm{x}}$ & $(\mathrm{S})$ & $7.4 \mathrm{a}$ & $(\mathrm{S})$ \\
Agura & $7.9 \mathrm{abc}$ & $(\mathrm{S})$ & $4.8 \mathrm{ab}$ & $(\mathrm{M})$ \\
All Star & $7.9 \mathrm{ab}$ & $(\mathrm{S})$ & $7.3 \mathrm{a}$ & $(\mathrm{S})$ \\
Tokiwa Power Z & $0.4 \mathrm{~d}$ & $(\mathrm{R})$ & $0.0 \mathrm{~b}$ & $(\mathrm{R})$ \\
PPMR-1 & $5.2 \mathrm{bcd}$ & $(\mathrm{M})$ & $4.0 \mathrm{ab}$ & $(\mathrm{M})$ \\
Shishigadani & $8.3 \mathrm{ab}$ & $(\mathrm{S})$ & $6.5 \mathrm{a}$ & $(\mathrm{S})$ \\
White Power & $0.7 \mathrm{~d}$ & $(\mathrm{R})$ & $0.4 \mathrm{~b}$ & $(\mathrm{R})$ \\
Shin-tosa & $8.2 \mathrm{ab}$ & $(\mathrm{S})$ & $4.4 \mathrm{ab}$ & $(\mathrm{M})$ \\
Encore 10 & $8.0 \mathrm{ab}$ & $(\mathrm{S})$ & $5.7 \mathrm{a}$ & $(\mathrm{S})$ \\
PI 197088-1 & $0.3 \mathrm{~d}$ & $(\mathrm{R})$ & $0.0 \mathrm{~b}$ & $(\mathrm{R})$
\end{tabular}

${ }^{\mathrm{z}}$ Disease index: $0=$ no symptom $-9=$ totally and thickly covered with hyphae and spores.

${ }^{y}$ Resistance Evaluation: S, susceptible; M, moderate resistant; R, resistant.

${ }^{x}$ Mean separation within columns by Kruskal and Wallis ANOVA at $P<0.05$.

Table 3. Powdery mildew resistance of rootstock cultivars grown in greenhouse.

\begin{tabular}{|c|c|c|c|c|}
\hline \multirow{3}{*}{ Rootstock cultivar } & \multicolumn{4}{|c|}{ Disease index ${ }^{z}$} \\
\hline & \multicolumn{2}{|c|}{ First true leaf } & \multicolumn{2}{|c|}{ Tenth true leaf } \\
\hline & \multicolumn{2}{|c|}{ Greenhouse in June $2002\left(\mathrm{RE}^{y}\right)$} & \multicolumn{2}{|c|}{ Greenhouse in June 2002 (RE) } \\
\hline Hikari Power Gold & $7.3 \mathrm{a}^{\mathrm{x}}$ & (S) & $5.0 \mathrm{a}$ & (S) \\
\hline Tokiwa Power Z & $0.0 \mathrm{~b}$ & (R) & $1.0 \mathrm{bc}$ & (R) \\
\hline PPMR-1 & $0.0 \mathrm{~b}$ & (R) & $0.0 \mathrm{c}$ & (R) \\
\hline White Power & $2.7 \mathrm{ab}$ & (M) & $1.0 \mathrm{bc}$ & $(\mathrm{R})$ \\
\hline Shin-tosa & $7.6 \mathrm{a}$ & (S) & $3.9 \mathrm{ab}$ & (M) \\
\hline Encore 10 & $6.1 \mathrm{a}$ & (S) & $2.6 \mathrm{ab}$ & (M) \\
\hline PI 197088-1 & $0.0 \mathrm{~b}$ & (R) & $0.0 \mathrm{c}$ & $(\mathrm{R})$ \\
\hline
\end{tabular}

${ }^{\mathrm{z}}$ Disease index: $0=$ no symptom $-9=$ totally and thickly covered with hyphae and spores

${ }^{y}$ Resistance Evaluation: S, susceptible; M, moderate resistant; R, resistant.

${ }^{x}$ Mean separation within columns by Kruskal and Wallis ANOVA at $P<0.05$. 
visible symptoms. The resistance of PM increased with further growth. TP and WP were also found to be resistant, with visible minimal, mycelial growth, on the leaves. HP, ST, and A10 were found to be susceptible to moderately resistant.

TP, WP, and PI were consistently resistant to powdery mildew from the cotyledonary stage to the adult stage at cool to moderate temperatures, whereas, PM exhibited moderate to high resistance, especially during the adult stage. The mechanisms of powdery mildew resistance may differ between the resistance of TP (or WP) and that of PM.

Powdery-mildew resistance of cucumber scions grafted onto rootstocks

The levels of powdery-mildew resistance in cucumber scions, grafted onto various rootstocks (Table 4), show that no differences in the powdery-mildew resistance of cotyledons, detached from scions grafted onto various rootstocks tested at $20^{\circ} \mathrm{C}$. However, the fifth true leaves of plants tested at $20^{\circ} \mathrm{C}$ and the seventeenth true leaves from plants tested in a plastic greenhouse, reacted differently that of the cotyledons. Fifth leaves of PMand ST-grafted plants showed some powdery-mildew resistance or tolerance, whereas those of HP- and A10grafted plants were susceptible; PI-grafted plants exhibited intermediate response. In the first seventeenthleaf experiment, PM-grafted plants were distinctly resistant (Fig. 1), whereas HP-, TP-, SS-, WP-, A10-, and PI-grafted plants were less resistant. However, in the second seventeenth-leaf experiment, HP-, TP-, and WP-grafted plants were less resistant or tolerant than

Table 4. Powdery mildew resistance in cucumber scions grafted onto various rootstock cultivars.

\begin{tabular}{|c|c|c|c|c|c|c|}
\hline \multirow{4}{*}{$\begin{array}{l}\text { A10/Rootstock cultivar } \\
\text { Hikari Power Gold }\end{array}$} & \multicolumn{6}{|c|}{ Disease index ${ }^{z}$} \\
\hline & \multirow{2}{*}{$\begin{array}{c}\text { Detached cotyledon } \\
20^{\circ} \mathrm{C}\left(\mathrm{RE}^{\mathrm{y}}\right)\end{array}$} & \multirow{2}{*}{$\begin{array}{l}\text { Fifth true leaf } \\
20^{\circ} \mathrm{C}(\mathrm{RE})\end{array}$} & \multicolumn{4}{|c|}{ 17th true leaf } \\
\hline & & & $\begin{array}{c}\text { (exp. 1) } \\
\text { Greenhouse in Jan. } \\
2002 \text { (RE) }\end{array}$ & \multicolumn{2}{|c|}{$\begin{array}{l}\text { (exp. 2) } \\
\text { Greenhouse in July } \\
2002 \text { (RE) }\end{array}$} & $\begin{array}{c}\text { (exp. 3) } \\
\text { Greenhouse in Nov. } \\
2004(\mathrm{RE})\end{array}$ \\
\hline & $4.7 \mathrm{~ns}^{\mathrm{x}} \quad(\mathrm{S})$ & $5.1 \mathrm{a}$ & $6.4 \mathrm{a}$ & $6.9 \mathrm{a}$ & (S) & $6.8 \mathrm{ab} \quad(\mathrm{S})$ \\
\hline Tokiwa Power Z & $2.6 \mathrm{~ns} \quad(\mathrm{~S})$ & $-^{\mathrm{w}}$ & $4.1 \mathrm{abc} \quad(\mathrm{S})$ & $6.9 \mathrm{a}$ & $(\mathrm{S})$ & - \\
\hline King Kitora & - & - & - & - & & $7.4 \mathrm{a}$ \\
\hline PPMR-1 & $2.9 \mathrm{~ns} \quad(\mathrm{~S})$ & $2.0 \mathrm{~b}$ & $0.4 \mathrm{~d}$ & $3.0 \mathrm{~cd}$ & (R) & $5.1 \mathrm{c}$ \\
\hline Shishigadani & - & - & $5.2 \mathrm{ab} \quad(\mathrm{S})$ & - & & - \\
\hline White Power & $3.2 \mathrm{~ns} \quad(\mathrm{~S})$ & - & $3.9 \mathrm{bc} \quad(\mathrm{S}-\mathrm{M})$ & $6.0 \mathrm{ab}$ & (S) & - \\
\hline Shin-tosa & $3.6 \mathrm{~ns} \quad(\mathrm{~S})$ & $2.6 \mathrm{~b} \quad(\mathrm{R})$ & - & $4.3 \mathrm{bc}$ & (M) & $5.8 \mathrm{bc} \quad(\mathrm{M})$ \\
\hline Encore 10 & $3.6 \mathrm{~ns} \quad(\mathrm{~S})$ & $5.5 \mathrm{a}$ & $3.8 \mathrm{bc} \quad(\mathrm{S}-\mathrm{M})$ & $2.7 \mathrm{~d}$ & (R) & $5.8 \mathrm{bc} \quad(\mathrm{M})$ \\
\hline PI 197088-1 & $2.1 \mathrm{~ns} \quad(\mathrm{~S})$ & $3.5 \mathrm{ab} \quad(\mathrm{M})$ & $3.2 \mathrm{c}$ & $1.8 \mathrm{~d}$ & (R) & - \\
\hline
\end{tabular}

${ }^{\mathrm{z}}$ Disease index: $0=$ no symptom $-9=$ totally and thickly covered with hyphae and spores.

${ }^{y}$ Resistance Evaluation: S, susceptible; M, moderate resistant; R, resistant.

${ }^{x}$ Mean separation within columns by Kruskal and Wallis ANOVA at $P<0.05$.

w Not examined.
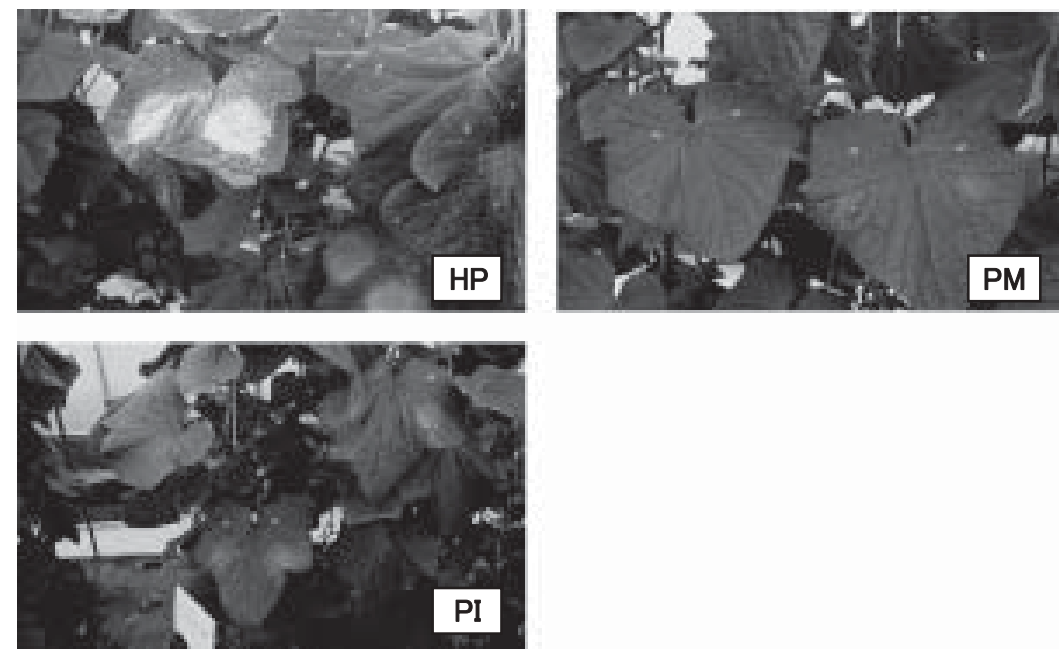

Fig. 1. Symptoms of powdery mildew in 17th leaves of scions grafted onto 'Hikari Power Gold' (HP), PPMR-1 (PM) and PI $197088-1$ (PI), 11 days after inoculation. Disease index of each plate is 9 (HP), 1 (PM), and 3 (PI), respectively. 
PM-, ST-, A10-, and PI-grafted plants. The results of the third seventeenth-leaf experiment were similar to those of the second experiment, except that scions, grafted onto the bloomless rootstock cultivar KK, were susceptible. Hence, HP and certain other bloomless rootstocks lowered the resistance to powdery mildew in contrast to the blooming rootstocks ST and others. These results are consistent with the findings that cucumbers grafted onto bloomless rootstocks were less resistant to powdery mildew than those grafted onto conventional rootstocks (Chiba and Tomita, 1993; Hazama et al., 1993; Morishita et al., 1999). This effect has been postulated to be related to a less-efficient absorption and distribution of $\mathrm{SiO}_{2}$ (Yamanaka and Sakata, 1993), which is thought to confer powdery mildew resistance, by bloomless rootstock cultivars than blooming-type rootstock cultivars (Motojima, 1991). However, the relationship between powdery-mildew resistance and the $\mathrm{SiO}_{2}$ concentrations in leaves of cucumbers is still unclear, because scions grafted onto the blooming cultivar of 'Shishigadani' (C. moschata) were very susceptible to powdery mildew. Thus, some of the blooming rootstock cultivars may bestow some resistance or tolerance to the scions; conversely; all of (or most of) the bloomless rootstock cultivars reduce the tolerance of the grafted scions.

The results of the seventeenth-leaf tests implied that the differences in resistance or tolerance between PMgrafted and ST-grafted plants may be small. However, PM is a good candidate for a new rootstock breeding material, because it shows moderate to high resistance to powdery mildew and imparts some resistance or tolerance to the scions. Furthermore, PM is an accession of $C$. moschata, that is easy to hybridize with other rootstock cultivars (C. moschata) used in Japan. Contrarily, ST is an interspecific hybrid that has some difficulty in hybridization with $C$. moschata or $C$. maxima.

The powdery-mildew-resistant rootstock TP and WP did not give a high level of resistance to scions in this study, nor in that of Sakiyama (personal communication). The differences in the resistances among TP- and WPgrafted and PM- and ST-grafted plants may be attributed to specific rootstock resistance mechanisms.

The reactions of scions grafted onto cucumber rootstocks were not consistent in this study, e.g., in a test of fifth leaves, A10-grafted plants were as severely damaged by powdery mildew as HP-grafted plants, but in the seventeenth leaf tests, the former showed more tolerance than did the latter. The inconsistency of the reactions of A10-grafted plants may be explained by the difference in their ages, climatic and pathological conditions. In the second seventeenth-leaf experiment, a natural infection with downy mildew (Pseudoperonospora cubensis [Berk. \& Curt] Rostow.) occurred on cucumber plants grafted onto A10 and PI rootstocks. It is possible that the reaction of the plants to downy mildew led to induced resistance to powdery mildew in this particular experiment.

The studies published on the resistance against foliar diseases or pests imparted by grafting with a resistant rootstock are limited. There have been no reports on foliar diseases and pest attack, whereas there are several reports on transferred resistance, e.g., the cowpea aphid (Aphis craccivora Koch) in cowpea (Vigna unguiculata (L.) W ALP.) (Ansari and Emden, 1989) and to the carmine spider mite (Tetranychus cinnabarinus Boisduval) in pumpkin (Cucurbita spp.) (Edelstein et al., 2000). We found some rootstock influences of grafting on scions, but further investigations are needed, especially for foliar diseases. In addition, the side effects of grafting, such as superior (or inferior) fruit quality, adaptability to climatic conditions, should be evaluated.

\section{Literature Cited}

Ansari, A. K. and H. F. van Emden. 1989. Graft-transmissibility of resistance to cowpea aphid, Aphis craccivora Koch (Hemiptera: Aphididae), in six highly antibiotic cowpea varieties. Bull. Ent. Res. 79: 393-399.

Chiba, T. and Y. Tomita. 1993. Influence of organic matter application and grafting on rootstocks to suppress blooms on cucumber fruit on disease development of cucumber powdery mildew (Sphaerotheca fuliginea). Proceedings of the Kanto-Tosan Plant Protection Society 40: 41-42 (In Japanese).

Edelstein, M., Y. Tadmor, F. Abo-Moch, Z. Karchi and F. Mansour. 2000. The potential of Lagenaria rootstock to confer resistance to the carmine spider mite, Tetranychus cinnabarinus (Acari: Tetranychidae) in Cucurbitaceae. Bull. Ent. Res. 90: 113-117.

Fujieda, K. 1994. Cucumber. p. 69-73. In: Organizing Committee XXIVth International Horticultural Congress Publication Committee (Ed.), Horticulture in Japan. Asakura, Tokyo.

Hazama, W., S. Morita and T. Kato. 1993. Resistance to Corynespora target leaf spot in cucumber grafted on a bloomless rootstock. Soc. Phytopath. Soc. Japan 59: 243 248 (In Japanese with English summary).

Morishita, M., Y. Sakata and K. Sugiyama. 1999. Effect on rootstock on incidence of powdery mildew in cucumber. J. Japan Soc. Hort. Sci. 68 (Suppl. 1): 513 (In Japanese).

Morishita, M., K. Sugiyama, T. Saito and Y. Sakata. 2002. An improved evaluation method for screening and selecting powdery mildew resistant cultivars and lines of cucumber (Cucumis sativus L.). J. Japan Soc. Hort. Sci. 71: 94-100 (In Japanese with English summary).

Motojima, T. 1991. Absorption characteristics of squash (Cucurbita pepo $\times$ C. moschata) used for cucumber rootstocks. Bull. Tochigi Agr. Exp. Stn. 38: 83-100 (In Japanese with English summary).

Oda, M. 2002. Grafting of vegetable crops. Sci. Rep. Agric. \& Biol. Sci., Osaka Pref. Univ. 54: 49-72.

Yamanaka, R. and M. Sakata. 1993. Singularity of silicic acid absorption and manganese toxicity on cucumber grafted on bloomless stock. Jap. J. Soil Sci. Plant Nutr. 64: 319 324 (In Japanese). 
台木品種がキュウリ穂木のうどんこ病抵抗性に及ぼす影響

\section{坂田好輝 ${ }^{1}$ 杉山充啓 ${ }^{1}$ 小原隆由 ${ }^{1} \cdot$ 森下昌三 ${ }^{2}$}

1農業・生物系特定産業技術研究機構野菜茶業研究所 514-2392 津市安濃町

2農業・生物系特定産業技術研究機構北海道農業研究センター 062-8555 札幌市豊平区羊ヶ丘

台木品種がキュウリ穂木のらどんこ病抵抗性に及ぼす 影響を明らかにするため，台木用品種そのもののらどん こ病抵抗性，また，抵抗性のレベルの異なる台木品種に 接ぎ木されたキュウリ穂木の抵抗性について評価した. 近年発表されたブルームレス台木 ‘ときわパワーZ’ 打 よび ‘ホワイトパワー'は, 子葉から第 10 本葉に至る まで, $20^{\circ} \mathrm{C}$ 程度の冷温から $26^{\circ} \mathrm{C}$, 加温八ウスレベルの 適温条件まで, 高いレベルのらどんこ病抵抗性を示した。 PPMR-1 は, 成育が進むにつれ, 高度な抵抗性を示した。 従来から利用されているブルームレス台木“ひかりパ ワーG’及びブルーム台木の ‘新土佐’は罹病性であり, ‘ひかりパワーG’ はより激しく罹病した. らどんこ病抵 抗性が異なる台木を用いた場合にも接ぎ木されたキュウ リ穂木の子葉の抵抗性には有意な差異はなく, 幼苗期に
扣いては台木品種が抵抗性に及ぼす影響はないまたは小 さいと考えられた。一方，接ぎ木キュウリの成育に伴い， PPMR-1 あるいは ‘新土佐’に接ぎ木された穂木（第 5 本葉，あるいは 17 本葉）は，らどんこ病に対して抵抗 性あるいは耐性を増した。 らどんこ病に高度な抵抗性を 有する ‘ときわパワーZ’ 执よび ‘ホワイトパワー’を 台木に用いた場合には，キュウリ穂木が抵抗性になるこ とはなかった。ブルームレス台木の ‘ひかりパワー G’ は穗木の抵抗性を弱めた. これらの結果から, 台木品種 は穂木のらどんこ病に対する抵抗性または耐性を変え, PPMR-1 のよらな抵抗性または耐性を付与することので きるカボチャ台木品種を利用することにより，らどんこ 病被害を軽減できることが示唆された。 